\title{
SERUM IGE LEVELS AND SEVERITY OF ATOPIC DERMATITIS
}

\author{
Binamra Basnet ${ }^{1}$, Saraswoti Neupane ${ }^{2}$, Shristi Shrestha ${ }^{3}$
}

\begin{abstract}
INTRODUCTION: Atopic dermatitis is an itchy, chronic relapsing, inflammatory skin condition with typical flexural distribution. The eruption is frequently associated with other atopic conditions in the individual or other family members . It is associated with increased production of serum IgE levels. The objective of this study is to evaluate whether serum IgE levels correlate with the severity of atopic dermatitis (AD) based on Three Item Severity (TIS) Score of AD
\end{abstract}

MATERIAL AND METHODS: This is a hospital based observational study carried out from June 2014 to January 2015. Eighty two atopic dermatitis patients aged $\leq 20$ years were recruited from the OPD of Dermatology Department of Gandaki Medical College, and the AD severity was evaluated using TIS score (Three Item Severity score). Concentrations of serum total IgE were measured and compared with controls.

RESULTS: The mean age of our study group comprising of 82 patients was $9.03 \pm 5.6$ years. The overall TIS score was $5.74 \pm 2.02$. To find out the correlation between the disease severity and IgE level, one way ANOVA test was used. There was no statistical difference between the IgE levels of controls and the patients with mild disease but there was a significant correlation between severity of disease (between mild, moderate and severe AD) and the levels of serum IgE. $(\mathrm{P}<0.05)$

CONCLUSION: Serum IgE is an useful indicator for predicting severity of atopic dermatitis in young patients.

KEY WORDS: Atopic dermatitis; Serum IgE levels

1. Lecturer, Department of Dermatology and Venereology, Gandaki Medical College, Pokhara, Nepal

2. Associate Professor, Department of Dermatology and Venereology, Gandaki Medical College, Pokhara, Nepal

3. Lecturer, Department of Ophthalmology, Manipal Medical College of Teaching Hospital, Pokhara, Nepal

\author{
For Correspondence \\ Dr. Binamra Basnet \\ Lecturer, \\ Department of Dermatology and Venereology, \\ Gandaki Medical College, Pokhara, Nepal \\ E-mail: binamrabasnet@gmail.com
}




\section{INTRODUCTION}

Atopic dermatitis is an itchy, chronically relapsing, inflammatory skin condition. The rash is characterized by itchy papules which become excoriated and lichenified, and typically have a flexural distribution. The eruption is frequently associated with other atopic conditions in the individual or other family members. ${ }^{1-3}$ It has a characteristic morphology and age-related distribution pattern of the involved skin and is associated with pruritus. Genetic factors play an important role, and the pathogenesis is attributable to specific immune and inflammatory mechanisms. Although the word "atopic" is in the name, association with atopy is not an essential criterion for atopic dermatitis (AD). So, patients diagnosed with $\mathrm{AD}$ can be atopic or non-atopic. ${ }^{4}$ The main immunoglobulin abnormality is increased production of IgE. This results in the presence of many antigen-specific $\operatorname{IgE}$ species to ingested or inhaled antigens and, mostly an increase in total serum IgE. About $80 \%$ of patients with atopic dermatitis have increased amount of total IgE. ${ }^{5}$

\section{MATERIAL AND METHODS}

The study was conducted in the Department of Dermatology \& Venereology, Gandaki Medical College, Pokhara, Nepal from June 2014 to Jan 2015. Patients belonging to both sexes and aged upto 20 years were included. Written informed consent and ethical clearance was taken. Patients with other dermatological and systemic problems and age more than twenty were excluded. In this study we included the patients of atopic dermatitis with varying severity. A total of 82 patients were included and 'The UK refinement of Hanifin and Rajka's diagnostic criteria' was used to diagnose cases of atopic dermatitis. ${ }^{6}$

None of the patients received any systemic corticosteroid or immunomodulatory treatment before being enrolled in the study. We classified the patients as mild, moderate or severe using the TIS score (Three Item Severity score). It is a simplified system, based on the evaluation of erythema, oedema/papulation and excoriation on a scale from 0 to 3 . The TIS score is the sum of 3 intensity items scored on a scale from 0 to 3. Each item should be scored on the most representative lesion. The range of the TIS score lies between 0 and 9 . Based on this system, AD can be classified as mild (total score 324), moderate (from $>4$ to $<8$ ) and severe (from $>8-9$ ). ${ }^{7}$ A written consent was taken from the patient and parents for the study. In addition to routine investigations, relevant investigations where required, were also carried out. These included scraping for fungus, swabs for culture \& sensitivity and histopathology. Sera of all these patients were tested for $\operatorname{IgE}$ levels by ELISA and their levels were graded to correlate with severity of the disease. Required number of age-matched controls were also investigated. All the findings were recorded on a preformed proforma. Data were collected and analysed using statistical software, SPSS Statistics, version 21. A 'p' value $<0.05$ was considered statistically significant.

\section{RESULTS}

In this study, we recruited 82 patients which comprised of 32 males (39\%) and 50 females (61\%); male to female ratio being 0.64 . The mean age was $9.03 \pm 5$.6years (range 6 months to 20 years). According to the severity of the disease, 28 patients had mild AD, 30 patients had moderate and 24 had severe disease. Around $50 \%$ of the patients were aged between 1 to 10 years, infants comprised less than $10 \%$ of the study group, the rest ranging from 11 to 20 years. The overall TIS score was $5.74 \pm 2.02,5$ patients scored 7 while 16 patients scored 8 .

Table 1: Gender wise age distribution

\begin{tabular}{|c|c|c|c|}
\hline Age Group & Male & Female & Total \\
\hline$<1$ & 2 & 4 & 6 \\
\hline $1-5$ & 9 & 11 & 20 \\
\hline $6-10$ & 6 & 15 & 21 \\
\hline $11-15$ & 7 & 14 & 21 \\
\hline$>15$ & 8 & 6 & 14 \\
\hline Total & $\mathbf{3 2}$ & $\mathbf{5 0}$ & $\mathbf{8 2}$ \\
\hline
\end{tabular}

Table 2: Disease severity in patients of different age groups

\begin{tabular}{|l|c|c|c|c|c|c|}
\hline Severity of Disease & \multicolumn{7}{|c|}{ Age group } & Total \\
\hline & $<1$ & $\mathbf{1 - 5}$ & $\mathbf{6 - 1 0}$ & $\mathbf{1 1 - 1 5}$ & $>\mathbf{1 5}$ & \\
\hline Mild & 1 & 8 & 6 & 7 & 6 & 28 \\
\hline Moderate & 2 & 6 & 8 & 10 & 4 & 30 \\
\hline Severe & 3 & 6 & 7 & 4 & 4 & 24 \\
\hline Total & $\mathbf{6}$ & $\mathbf{2 0}$ & $\mathbf{2 1}$ & $\mathbf{2 1}$ & $\mathbf{1 4}$ & $\mathbf{8 2}$ \\
\hline
\end{tabular}

We divided the patients into three groups (mild, moderate and severe) based on the severity of AD using The TIS score. ${ }^{7}$ In the first group, there were 28 patients, likewise 30 and 24 in the other two groups respectively. Twenty-four healthy 
controls were also included in our study. The mean value of serum $\mathrm{IgE}$ for mild, moderate and severe disease were $153.89 \pm 49.71 \mathrm{IU} / \mathrm{ml}, 217.03 \pm 113.50 \mathrm{IU} / \mathrm{ml}$ and $319.50 \pm 197.78 \mathrm{IU} / \mathrm{ml}$ respectively (Table 3 )

\section{Table 3: Mean IgE values of cases and control}

\begin{tabular}{|l|c|c|c|c|c|}
\hline Group & Number & Mean & Std.Deviation & \multicolumn{2}{|c|}{ 95\% CI* for Mean } \\
\hline & & & & Lower bound & Upper bound \\
\hline Controls & 24 & 126.75 & 39.986 & 109.87 & 143.63 \\
\hline Mild & 28 & 153.89 & 49.710 & 134.62 & 173.17 \\
\hline Moderate & 30 & 217.03 & 113.501 & 174.65 & 259.42 \\
\hline Severe & 24 & 319.50 & 197.784 & 235.98 & 403.02 \\
\hline
\end{tabular}

*CI-Confidence Interval

To find out the correlation between the disease severity and IgE level we used one way ANOVA test. A statistically positive correlation between the severity of disease and the level of IgE was found. ( $p$ value $<0.05$ ) When we compared the IgE level of controls and the patients, there was no statistical difference between the controls and the patients with mild disease but there was a significant statistical difference between mild, moderate and severe disease ( $p$ value $<0.05)$ as depicted below in Table 4. As shown in Fig.1, an inclining curvilinear graph is seen as the severity of the disease increases.

Table 4: Comparison between various groups and controls

\begin{tabular}{|c|l|c|c|}
\hline \multicolumn{2}{|c|}{ Comparison between cases and controls } & $\begin{array}{c}\text { Mean } \\
\text { Difference }\end{array}$ & p-Value \\
\hline \multirow{3}{*}{ Controls } & Mild & -27.1429 & .403 \\
\cline { 2 - 4 } & Moderate & $\mathbf{- 9 0 . 2 8 3 3}$ & $\mathbf{. 0 0 5}$ \\
\cline { 2 - 4 } & Severe & $\mathbf{- 1 9 2 . 7 5 0 0}$ & $\mathbf{. 0 0 1}$ \\
\hline \multirow{3}{*}{ Mild } & Controls & 27.1429 & .403 \\
\cline { 2 - 4 } & Moderate & $\mathbf{- 6 3 . 1 4 0 5}$ & $\mathbf{. 0 4 1}$ \\
\cline { 2 - 4 } & Severe & $\mathbf{- 1 6 5 . 6 0 7 1}$ & $\mathbf{. 0 0 1}$ \\
\hline \multirow{3}{*}{ Moderate } & Controls & $\mathbf{9 0 . 2 8 3 3}$ & $\mathbf{. 0 0 5}$ \\
\cline { 2 - 4 } & Mild & $\mathbf{6 3 . 1 4 0 5}$ & $\mathbf{. 0 4 1}$ \\
\cline { 2 - 4 } & Severe & $\mathbf{- 1 0 2 . 4 6 6 7}$ & $\mathbf{. 0 0 2}$ \\
\hline \multirow{3}{*}{ Severe } & Controls & $\mathbf{1 9 2 . 7 5 0 0}$ & $\mathbf{. 0 0 1}$ \\
\cline { 2 - 4 } & Mild & $\mathbf{1 6 5 . 6 0 7 1}$ & $\mathbf{. 0 0 1}$ \\
\cline { 2 - 4 } & Moderate & $\mathbf{1 0 2 . 4 6 6 7}$ & $\mathbf{. 0 0 2}$ \\
\hline
\end{tabular}

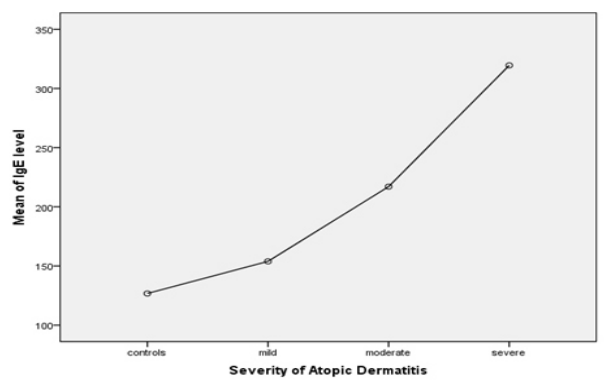

Figure 1: Correlation of disease severity and the mean level of IgE(IU/ml)

\section{DISCUSSION}

Immunoglobulin $\mathrm{E}$ ( $\mathrm{IgE}$ ) has a unique position among immunoglobulins. It is present in human serum in very small amount, its serum concentration may increase several folds in response to specific stimuli. ${ }^{\mathbf{8} 9}$ The levels are raised in allergic diseases like allergic rhinitis, allergic bronchial asthma, atopic dermatitis and urticaria. ${ }^{10-16} \mathbf{A}$ child with atopy produces IgE antibodies after exposure to some environmental allergens. ${ }^{17}$ Elevated serum IgE level occurs in around $80 \%$ of patients with atopic dermatitis and are directed against a variety of antigens e.g. pollens, moulds, foodstuff, house dust mites and bacterial antigens. Patients with atopic dermatitis show positive Prick test and RAST to food allergens such as egg, milk, wheat, fish, soya and peanuts. ${ }^{18-21}$ In atopic dermatitis the partial loss of the cutaneous barrier function, due to low ceramide levels and reduced filaggrin function, facilitates the transepidermal water loss and the penetration of environmental antigens, resulting in a specific, IgE-driven, allergic skin inflammation., 22,23

IgE activates key effector cell types involved in allergic inflammation and its contribution to some of other allergic diseases in which patients are sensitized to allergens and have elevated levels of IgE. ${ }^{24}$ The result of the present study in which the severity of atopic dermatitis correlating with the $\operatorname{IgE}$ level is in accordance with the study conducted by Ahmed et $a l$. The authors concluded that children suffering from atopic dermatitis had raised serum level of IgE, which also correlated well with severity of the disease. In their study, only mild and severe disease group had a significant correlation with the $\operatorname{IgE}$ levels. ( $p$ value $<0.001$ ) The authors did not compare the values of the patients with that of controls, rather they divided IgE levels into three groups, cut off being $87 \mathrm{IU} / \mathrm{ml} .^{25}$ Dhar et al. carried out a study on 102 atopic patients and found that IgE levels in these patients were significantly higher than that of the controls. ${ }^{26}$ Similar findings with additional association to respiratory disease were observed by Johnson et al. ${ }^{27}$ In a case control study of 2,201 East German school children aged 5 to 14 years, the investigators found elevated serum levels of total $\mathrm{IgE}$ and $\operatorname{IgE}$ specific to various aeroallergens in $75 \%$ children with $\mathrm{AD}$; this was significantly higher than those without $\mathrm{AD}(36.3 \%){ }^{28}$ In another study of 345 children (mean age, 2.9 years), it was found that children with $A D$ had a higher prevalence (about $80 \%$ ) of sensitization to food and a medium 
prevalence (about $40 \%$ ) to aeroallergens and also the mean serum IgE level in children with high SCORAD quartile was significantly higher than in the low SCORAD quartile (5443 $\mathrm{kU} / 1$ vs. $488 \mathrm{kU} / 1, \mathrm{p}$ value $<0.001) .{ }^{29}$ In yet another multicenter study of a German birth cohort, investigators followed 1,314 children from birth to 7 years of age and determined serum IgE antibodies specific to food allergens (cow's milk, egg white, soya bean and wheat) and inhalant allergens (house dust mite, cat dander, mixed-grass, and birch pollen) by using an immunoassay. They found a strong association of $\mathrm{AD}$ with elevated total and specific IgE levels at the age of 2 . The association was higher at younger age: $41 \%$ of children with sensitization at age 1 had $\mathrm{AD}$, whereas only $27 \%$ children with onset of sensitization after age 2 had $\mathrm{AD} .^{30}$

In a prospective study comprising 50 patients of $\mathrm{AD}, 88 \%$ were found to have elevated levels of serum IgE with the highest elevation seen in those between the ages of 10 to 20 years. This study also noted an age dependence in the pattern of sensitization. $65 \%$ of the children under the age of 10 were positive to one or more food allergens; sensitivity to food allergens was more common in those below 10 , while that to aeroallergens was more common in the older age children. ${ }^{31}$ According to Hon et al., the total serum IgE level divided by the age-specific upper limit correlated well with the extent and intensity of AD as per SCORAD scores. ${ }^{32}$

\section{CONCLUSION}

The present study shows that the level of IgE correlates remarkably with the severity of atopic dermatitis. Further studies with greater sample size are needed to consolidate our findings.

\section{ACKNOWLEDGEMENTS}

We are very grateful to Mr Sujan Gautam and Dr. Dev Kumar Thapa for their help in this study.

\section{REFERENCES}

1. Darsow U, Lübbe J, Taïeb A, Seidenari S, Wollenberg A, Calza AM, et al. European Task Force on Atopic Dermatitis. Position paper on diagnosis and treatment of atopic dermatitis. $J$ Eur Acad Dermatol Venereol 2005; 19(3):286-95.

http://dx.doi.org/10.1111/j.1468-3083.2005.01249.x PMid:15857453
2. Williams HC. Clinical practice. Atopic dermatitis. N Engl J Med 2005;352(22):231424.

http://dx.doi.org/10.1056/NEJMcp042803 PMid:15930422

3. Brown S, Reynolds NJ. Atopic and non-atopic eczema. BMJ 2006;332:5848.

http://dx.doi.org/10.1136/bmj.332.7541.584 PMid:16528081 PMCid:PMC1397720

4. Liu FT, Goodarzi H, Chen HY. IgE, Mast Cells and Eosinophils in Atopic Dermatitis .Clinic Rev Allerg Immunol 2011;41(3):298310.

http://dx.doi.org/10.1007/s12016-011-8252-4 PMid:21249468

5. Cookson WO, Ubhi B, Lawrence R, Abecasis GR, Walley AJ, Cox $H E$, et al. Genetic linkage of childhood atopic dermatitis to psoriasis susceptibility loci. Nat Genet 2001;27(4):372-3. http://dx.doi.org/10.1038/86867 PMid:11279517

6. Williams HC, Burney PG, Pembroke AC, Hay RJ. Validation of the U.K. diagnostic criteria for atopic dermatitis in a population setting. U.K. Diagnostic Criteria for Atopic Dermatitis Working Party. Br J Dermatol 1996;135(1):1217.

http://dx.doi.org/10.1046/j.1365-2133.1996.d01-925.x PMid:8776351

7. Wolkerstorfer A, de Waard van der Spek FB, Glazenburg EJ, Mulder PG, Oranje AP. Scoring the severity of atopic dermatitis: three item severity score as a rough system for daily practice and as a pre-screening tool. Acta Derm Venereol 1999;79(5):356-9. http://dx.doi.org/10.1080/000155599750010256 PMid:10494710

8. Ishizaka K, Ishizaka T, Hornbrook MM. Allergen-binding activity of gamma-E, gamma-G and gamma-A antibodies in sera from atopic patients. In vitro measurements of reaginic antibody. J. Immunol 1967;98(3):490-492. PMid:4164056

9. Wide L, Bennich H, Johansson S.G. Diagnosis of allergy by an in-vitro test for allergen antibodies. Lancet 1967;2:1105-1107. http://dx.doi.org/10.1016/S0140-6736(67)90615-0

10. Johansson SG. Serum IgND levels in healthy children and adults. Int Arch Allergy Appl Immunol 1968;34(1):1-3. http://dx.doi.org/10.1159/000230089 PMid:4174442

11. Bazaral M, Orgel A, Hamberger R.A. Genetic of IgE and allergy: Serum IgE levels in twins. Allergy Clin Immunol 1974;54:288304.

http://dx.doi.org/10.1016/0091-6749(74)90015-3

12. Henderson LL, Swedlund HA, Van Dellen RG, Marcoux JP, Carryer HM, Peters GA, et al. Evaluation of IgE tests in allergy practice. JAllergy Clin Immunol 1971;48:361-5.

http://dx.doi.org/10.1016/0091-6749(71)90082-0

13. Kumar L, Newcomb RW, Hombrook MA. A year round study of serum IgE levels in asthmatic children. J Allergy Clin Immunol 1971;48:305-312.

http://dx.doi.org/10.1016/0091-6749(71)90032-7 
14. Hoffman DR, Yamamoto FY, Geller V, Haddad Z. Specific IgE antibodies in atopic eczema. $J$ Allergy Clin Immunol 1975;55:256-267. http://dx.doi.org/10.1016/0091 6749(75)90145-1

15. McGeady SJ, Buckley RH. Depression of cell mediated immunity in atopic eczema. J Allergy Clin Immunol 1975;56:393-406. http://dx.doi.org/10.1016/0091-6749(75)90133-5

16. Orgel HA, Hamburger RN, Bazaral M, Gorrin H, Groshong T, Lenoir $M$ et al. Development of IgE and allergy in infancy. $J$ Allergy Clin Immunol 1975; 56:296-307.

http://dx.doi.org/10.1016/0091-6749(75)90104-9

17. Cookson WO, Ubhi B, Lawrence R, Abecasis GR, Walley AJ, Cox $H E$, et al. Genetic linkage of childhood atopic dermatitis to psoriasis susceptibility loci. Nat Genet 2001;27:372-3. http://dx.doi.org/10.1038/86867 PMid:11279517

18. Bunkowski R. Prevalence and role of serum IgE antibodies to the Staphylococcus aureus-derived super antigens SEA and SEB in children with atopic dermatitis. J Allergy Clin Immunol 1999;103:119-24. http://dx.doi.org/10.1016/S0091 6749(99)70535-X

19. Nissen D. IgE-binding components of staphylococcal enterotoxins in patients with atopic dermatitis. Ann Allergy Asthma Immunol 1997;79:403-8.

http://dx.doi.org/10.1016/S1081-1206(10)63033-5

20. Paller AS. Atopic Dermatitis: Current therapy in allergy, immunology and rheumatology; Fifth Ed Edited by Liechtenstein LM and Fauci AS. 5th Edition 1996;pp 83-6.

21. Sicherer S, Sampson H. Food hypersensitivity and atopic dermatitis: pathophysiology, epidemiology, diagnosis and management. JAllergy Clin Immunol 1999;104:114-22. http://dx.doi.org/10.1016/S0091-6749(99)70053-9

22. Osawa R, Akiyama M, Shimizu H. Filaggrin gene defects and the risk of developing allergic disorders. Allergol Int 2011; 60:19. http://dx.doi.org/10.2332/allergolint.10-RAI-0270 PMid:21173567

23. Wang IJ, Lin TJ, Kuo CF, Lin SL, Lee YL, Chen PC. Filaggrin polymorphism P478S, IgE level, and atopic phenotypes. Br J Dermatol 2011;164:791796. http://dx.doi.org/10.1111/j.1365-2133.2011.10212.x PMid:21219289

24. Liu FT, Goodarzi H, Chen HY. IgE, mast cells, and eosinophils in atopic dermatitis. Clin Rev Allergy Immunol 2011;41(3):298310. http://dx.doi.org/10.1007/s12016-011-8252-4 PMid:21249468

25. Ahmed I, Nasreen S. Frequency of raised serum IgE level in childhood atopic dermatitis. J Pak Med Assoc 2007;57(9):4314. PMid:18072635
26. Dhar S, Malakar R, Chattopadhyay S, Dhar S, Banerjee R, Ghosh A. Correlation of the severity of atopic dermatitis with absolute eosinophil counts in peripheral blood and serum IgE levels. Indian J Dermatol Venereol Leprol 2005;71(4):246-9. http://dx.doi.org/10.4103/0378-6323.16615 PMid:16394432

27. Johnson EE, Irons JS, Patterson R, Roberts M. Serum IgE concentration in atopic dermatitis. Relationship to severity of disease and presence of atopic respiratory disease. J Allergy Clin Immunol 1974;54(2):94-9.

http://dx.doi.org/10.1016/0091-6749(74)90037-2

28. Schafer T, Heinrich J, Wjst M, Adam H, Ring J, Wichmann HE, et al. Association between severity of atopic eczema and degree of sensitization to aeroallergens in schoolchildren. J Allergy Clin Immunol 1999; 104(6): 12801284. http://dx.doi.org/10.1016/S0091-6749(99)70025-4

29. Laske N, Niggemann B. Does the severity of atopic dermatitis correlate with serum IgE levels? Pediatr Allergy Immunol 2004; 15(1):8688.

http://dx.doi.org/10.1046/j.0905-6157.2003.00106.x PMid:14998387

30. Illi S, von Mutius E, Lau S, Nickel R, Gruber C, Niggemann B, et al. The natural course of atopic dermatitis from birth to age 7 years and the association with asthma. J Allergy Clin Immunol 2004;113(5):925931.

http://dx.doi.org/10.1016/j.jaci.2004.01.778 PMid:15131576

31. Somani VK. A study of allergen-specific IgE antibodies in Indian patients of atopic dermatitis. Indian J Dermatol Venereol Leprol 2008;74(2): 100104 .

http://dx.doi.org/10.4103/0378-6323.39689 PMid:18388364

32. Hon KL, Lam MC, Leung TF, Wong KY, Chow CM, Fok TF, et al. Are age-specific high serum IgE levels associated with worse symptomatology in children with atopic dermatitis? Int $J$ Dermatol 2007;46(12):1258-62.

http://dx.doi.org/10.1111/j.1365-4632.2007.03407.x 